\title{
ע Ikääntyneiden kokemukset hoivan ja avun saamisesta koronapandemian aikana
}

\author{
Mari Aaltonen ${ }^{1}$, Jutta Pulkki $^{1}$, Pia Teräväinen ${ }^{1}$, Leena Forma $^{1,2,3}$ \\ ${ }^{1}$ Yhteiskuntatieteiden tiedekunta (terveystieteet) ja Gerontologian tutkimuskeskus, Tampereen yliopisto \\ ${ }^{2}$ Valtiotieteellinen tiedekunta, Helsingin yliopisto \\ ${ }^{3}$ Laurea-ammattikorkeakoulu
}

\begin{abstract}
Koronaviruspandemian rajoittamiseen liittyvät ensimmäiset toimenpiteet ja seuraukset kohdistuivat erityisesti ikääntyneisiin. Sosiaali- ja terveyspalvelujen resursseja kohdennettiin uudelleen ja osa palveluista suljettiin. Samanaikaisesti lähikontaktien välttäminen vaikeutti omaisten tarjoamaa apua. Selvitimme puolistrukturoitujen haastattelujen $(\mathrm{N}=16)$ laadullisen teema-analyysin avulla, miten yksityisessä kodissa tai tehostetussa palveluasumisessa asuvien ihmisten avun saaminen muuttui ja miten he suhtautuivat lähikontaktien välttämiseen sekä mahdollisiin muutoksiin avun saamisessa. Kahdeksassa haastattelussa kerrottiin muutoksia tapahtuneen, seitsemässä taas ei. Yhden asumispalveluissa asuvan henkilön tilanne jäi epäselväksi. Jaoimme kuvaukset kolmeen teemaan. Neutraalit kuvaukset eivät olleet myönteisiä eivätkä kielteisiä, ja ne liittyivät yleensä vähäisiin muutoksiin. Sopeutumista kuvasi se, että henkilöt pyrkivät ilmaisemaan mahdollista haittaa aiheuttaneiden muutosten lisäksi jotain myönteistä ja keksimään uusia toimintatapoja. Huolta aiheutti epäselvyys hoidon järjestämisessä tai järjestämistavoissa sekä ahdistus läheisten tapaamattomuudesta. Kotona asumista suosiva hoivapolitiikka on varautunut puutteellisesti äkillisiin kriisitilanteisiin etenkin niiden kohdalla, jotka ovat huomattavassa määrin omaisten avun varassa. Tämä joukko tarvitsisi joustavampia avunsaantimuotoja kuin koronapandemian yhteydessä on pystytty suosittelemaan tai tarjoamaan.
\end{abstract}

\section{Tausta}

Keväällä 2020 maailmanlaajuisesti levinnyt koronaviruspandemia mullisti erityisesti iäkkäiden ihmisten arkea monella tavalla. Mitä vanhemmista ihmisistä on kyse, sitä yleisempää on koronaviruksen aiheuttaman taudin (covid-19) vaarallisin muoto, joka voi johtaa sairaalahoitoon ja jopa kuolemaan (Verity ym. 2020).
Koronakuolleisuus on keskittynyt vanhimpiin ikäluokkiin ja etenkin hoivakodeissa asuviin (Comas-Herrera ym. 2020). Huhtikuuhun 2021 mennessä koronaviruksen aiheuttamaan tautiin kuolleiden keski-ikä oli Suomessa 84 vuotta (THL 2021). Tämän vuoksi koronaviruksen leviämisen pysäyttämiseksi asetetut ensimmäiset rajoitustoimet koskivat erityisesti 70 vuotta täyttäneitä henkilöitä. Heitä keho- 
tettiin välttämään lähikontakteja ja liikkumista kodin ulkopuolella eli elämään karanteenin kaltaisissa olosuhteissa (Valtioneuvosto 2020a). Yksi Suomen koronastrategian painopisteistä on ollut rajoittaa terveydenhuoltojärjestelmän taakkaa (Ylinen ym. 2021), ja tartuntojen ehkäiseminen ja hidastaminen palvelevat tätä tarkoitusta.

Ikääntyneiden koronapandemiaan liittyviä ajatuksia ja kokemuksia on tutkittu jo jonkin verran (esim. Petzold ym. 2020; Fuller \& Huseth-Zosel 2021; Pearman ym. 2021; Whitehead \& Torossian 2021). Toistaiseksi vähemmän on kuitenkin tutkittu pandemian aikaisia hoidon, hoivan ja avun (myöhemmin: apu) saamisen muutoksia ja sitä, miten mahdollisiin muutoksiin on suhtauduttu. Tässä tutkimuksessa selvitämme, miten yksityisessä kodissa tai tehostetussa palveluasumisessa (myöhemmin: asumispalveluyksikkö) asuvat ihmiset 1) kertovat koronatilanteen vaikuttaneen heidän kohdallaan sosiaali- ja terveyspalveluista sekä omaisilta saatavaan apuun, ja 2) miten he suhtautuivat lähikontaktien välttämiseen ja mahdollisiin muutoksiin avun saamisessa. Tarkastelemme rajoitustoimista lähikontaktien välttämistä, koska se kohdistettiin erityisesti ikääntyneisiin, ja oletamme sillä olleen vaikutusta ikääntyneiden avunsaantiin. Tulokset antavat tietoa siitä, miten ja millaiset avun saamisen muutokset tuottavat haittaa ja haasteita arjessa selviytymiseen sekä miten mahdollisesti tuleviin vastaaviin tilanteisiin varautumista voisi parantaa.

\section{Hoidon ja avun saannin muutokset koronapandemian aikana}

Keväällä 2020 sosiaali- ja terveydenhuollon resurssit kohdennettiin uudelleen vastaamaan paremmin koronavirustartuntojen myötä muuttuneisiin tarpeisiin. Muualla kuin julkisella sektorilla työskentelevien terveyden- ja sosiaalihuollon ammattilaisten oli tarkoitus tarvittaessa siirtyä työskentelemään julkiselle sektorille; julkisella sektorilla ei-kiireellisissä palveluissa työskentelevien taas oli tarkoitus siirtyä koronavirustartunnan saaneiden potilaiden hoitoon (Tiirinki ym. 2020). Lisäksi terveydenhuollon ja sosiaalipalvelujen kapasiteettia päätettiin lisätä sekä julkisella että yksityisellä sektorilla vähentämällä ei-kiireellisiä toimenpiteitä ja käyntejä. Esimerkiksi useiden pitkäaikaisten sairauksien rutiinitarkastuksia siirrettiin myöhemmäksi, samoin monia ei-kiireellisiä leikkauksia. (Forma ym. 2020; Tiirinki ym. 2020; Ylinen ym. 2021.)

Resurssien uudelleenkohdentamisen lisäksi osa palveluista suljettiin tartuntariskin pienentämiseksi tai palveluissa otettiin käyttöön uudenlaisia rajoituksia. Ikääntyneille ihmisille harrastustoimintaa tarjoavien sekä omaishoitoa tukevien vertaistukiryhmien toiminta keskeytettiin ja päiväkeskuksia suljettiin (Forma ym. 2020; Valtioneuvosto 2020b; Ylinen ym. 2021). Vierailut ikääntyneiden ja muiden riskiryhmien asumispalveluyksiköissä kiellettiin, samoin ulkopuolisten vierailut hoitolaitoksissa, terveydenhuollon yksiköissä ja sairaaloissa (Valtioneuvosto 2020b).

Vahva suositus lähikontaktien välttämisestä koski myös omaisia, jotka normaalisti auttoivat kotona asuvaa läheistään mutta eivät asuneet apua tarvitsevan henkilön kanssa samassa taloudessa. Koska ikääntyneet saavat apua omaisilta ja muilta läheisiltä useammin kuin julkisista palveluista (Finne-Soveri ym. 2014; Van Aerschot 2014), suositus lähikontaktien välttämisestä ja asumispalveluyksiköiden vierailukielto todennäköisesti vaikuttivat omaisten tarjoamaan apuun. Myös asumispalveluyksiköissä asuvat saavat usein apua omaisiltaan (Cohen ym. 2014; Pirhonen \& Pietilä 2015), joten vierailukielto todennäköisesti vaikutti heidänkin tilanteeseensa. Uusien viestintäteknologioiden käyttöönotto helpotti yhteydenpitoa läheisiin, mutta huoli tilanteesta ja epätietoisuus asumispalveluyksiköiden vierailukiellon kestosta heikensivät omaisten hyvinvointia (Pirhonen ym. 2020). Samassa taloudessa asuvien omaishoitajien hoitovastuu kasvoi virallisten palvelujen saatavuuden supistuessa 
tai keskeytyessä. Esimerkiksi päiväkeskusten toiminta ja lyhytaikaishoidot, joita käytetään omaishoitajien lomien mahdollistamiseen, olivat tauolla monilla paikkakunnilla, mikä saattoi lisätä omaishoitajan kuormittuneisuutta (Forma ym. 2020; Sariola 2021).

\section{Koronapandemian tuomiin haasteisiin} suhtautuminen ja niistä selviytyminen

Koronapandemia on aiheuttanut ahdistusta ja masennusta osalle kaikenikäisistä ihmisistä (Petzold ym. 2020), mutta Pearmanin ja kumppaneiden (2021) tutkimuksen mukaan vanhoille ihmisille huoli koronaviruksen aiheuttamaan tautiin sairastumisesta on tuottanut suurempaa ahdistusta kuin nuoremmille. Lähikontaktien välttäminen eli sosiaalinen eristäytyminen sekä palvelujen keskeyttäminen tai niihin kohdistuneet sosiaalisen toiminnan rajoitukset tuottivat osalle ikääntyneistä stressiä ja ulkopuoliseksi jäämisen kokemuksia (Pirhonen ym. 2021). Whiteheadin ja Torossianin (2021) mukaan eniten huolta ikääntyneille aiheuttivat koronapandemian mukanaan tuomat rajoitukset ja eristäytyminen, huoli läheisistä ja yksinäisyys. Toisaalta kyky ennakoida ja varautua muutoksiin vähensivät stressiä vanhoilla ihmisillä nuoria enemmän (Pearman ym. 2021). Fullerin ja Huseth-Zoselin (2021) mukaan yli 70-vuotiaat selviytyivät pääosin hyvin ja he näyttivät olevan mukautumiskyisiä ja joustavia suhteessa koronapandemian arkielämään tuomiin muutoksiin kuten lähikontaktien välttämiseen. He raportoivat positiivisen ajattelutavan, sosiaalisen tuen ja kiireisenä pysymisen edistävän selviytymistä kriisin aikana.

\section{Aineisto}

Tässä tutkimuksessa käytettävä haastatteluaineisto kerättiin alun perin Ikääntyneiden hoidon kustannukset ja rahoitus -pilottitutkimusta varten. Aineistonkeruu aloitettiin vuo- den 2020 alussa, ennen kuin koronapandemia oli alkanut. Haastatteluaineistoa kerättiin puolistrukturoiduilla teemahaastatteluilla kolmena kertana. Selvitimme muun muassa millaista apua tutkittavat tarvitsevat, ketkä heitä auttavat sekä millaisia sosiaali- ja terveyspalveluja he käyttävät. Ennen kolmatta haastattelukierrosta alkoi koronapandemia, ja viruksen leviämisen ehkäisemistä tavoittelevat rajoitustoimet tulivat voimaan. Tämä esti haastattelijan ja haastateltavan fyysisen tapaamisen kolmannella haastattelukerralla, joten viimeiset haastattelut toteutettiin puhelimitse. Koska rajoitustoimilla oli vaikutusta myös tutkimuksemme keskeisiin aiheisiin, kuten sosiaali- ja terveyspalvelujen käyttöön ja omaisilta saatavaan apuun, sisällytimme puhelinhaastatteluihin koronapandemiaan liittyviä kysymyksiä.

Tässä tutkimuksessa käytämme aineistona kolmannen kerran haastatteluja $(\mathrm{N}=16)$, jotka sisältävät koronaan liittyviä keskusteluja. Aineistossamme on kuusi kotihoidon asiakasta, joista kaksi osallistui haastatteluun yhdessä omaisen kanssa (6 haastattelua, 8 henkilöä). Asumispalveluyksiköstä osallistui 10 haastateltavaa, joista seitsemän oli sijaisvastaajana toimivia omaisia, ja kolme asumispalvelun asiakasta vastasi itse (yhteensä 10 henkilöä). Haastateltavilta kysyttiin, mitä he ajattelivat tilanteesta ja rajoitustoimista, oliko virallisessa tai omaisten tarjoamassa avussa tapahtunut muutoksia ja miten he olivat selvinneet arjen askareista poikkeusoloissa. Haastateltavat saivat kertoa myös vapaasti kaikista koronapandemiaan liittyvistä kokemuksistaan. Litteroitua aineistoa kertyi kolmannella haastattelukerralla 104 sivua (kotihoito 40, asumispalveluyksikkö 64 sivua), rivivälillä 1 ja fontilla Verdana 8.

Tutkimukseen osallistujat rekrytoitiin yhden kunnan järjestämän kotihoidon ja tehostetun palveluasumisen asiakkaiden joukosta. Otos oli harkinnanvarainen, sillä siihen oli tavoitteena sisällyttää asiakkaita, joilla oli vaihtelevia palvelutarpeita (RAI-arviointivälineen mukaan). Mahdolliset osallistujat valitsi kaksi kunnan palvelujen edustajaa, yksi kotihoidosta 
ja toinen tehostetusta palveluasumisesta. Tutkittavien rekrytoinnin kriteeri oli, että henkilö pystyi antamaan haastattelun tai hänellä oli omainen, jota voitiin haastatella. Kunnan edustajat kysyivät alustavaa halukkuutta osallistua tutkimukseen ja antoivat tutkijoille mahdollisten osallistujien yhteystiedot. (Aineistonkeruun tarkempi kuvaus, ks. Teräväinen 2021.)

Tutkimukselle on saatu puoltava lausunto Tampereen yliopistollisen sairaalan erityisvastuualueen alueelliselta eettiseltä toimikunnalta sekä tutkimuslupa kunnalta, jossa tutkimus toteutettiin. Haastateltaville annettiin sekä suullista että kirjallista tietoa tutkimuksesta. Heille kerrottiin, että tutkimukseen osallistuminen on vapaaehtoista ja sen voi keskeyttää halutessaan koska tahansa. Haastateltavat antoivat kirjallisen, tietoon perustuvan suostumuksensa osallistua tutkimukseen. Analyysi tehtiin pseudonymisoidulla aineistolla. Aineisto suojattiin salasanoin ja tallennettiin suojatulle verkkolevylle, mihin ei ollut pääsyä muilla kuin tutkimusryhmän jäsenillä.

\section{Analyysi}

Teema-analyysimme seuraa Braunin ja Clarken (2006) temaattisen analyysin ohjeita ja vaiheita. Ensin luimme litteroidut aineistot ja seuraavassa vaiheessa erottelimme haastatteluista koronatilannetta käsittelevät keskustelut. Jaottelimme haastattelut sen mukaan, missä määrin haastateltavat kuvasivat hoidon ja avun saamisessa tapahtuneita muutoksia. Haastateltavien saama hoito, hoiva ja apu sekä erilaiset tukipalvelut olivat hyvin moninaisia, ja niiden merkitys heidän arjessaan oli yksilöllistä. Tämän vuoksi käsitämme hoitona, hoivana ja apuna kaikki haastateltavien mainitsemat niin sanotut viralliset palvelut, joihin kuulu- vat kaikki ikääntyneiden käyttämät sosiaali- ja terveyspalvelut, erilaiset tukipalvelut ja päivätoimintaan osallistuminen, sekä omaisten tarjoaman avun ja tuen. Poimimme keskusteluja ja kommentteja, jotka kuvasivat koronapandemiaan ja sen tuomiin muutoksiin suhtautumista. Avainsanoja tai -lauseita olivat esimerkiksi ilmaisut, joissa kuvattiin harmia, pettymystä, huolta, huolettomuutta, uusia ideoita, tyytymättömyyttä tai tyytyväisyyttä.

Apua tarvitsevien henkilöiden ja omaisten puheet oli alun perin tarkoitus analysoida erikseen, mutta analyysia tehdessämme huomasimme, miten yhteen kietoutuneita molempien kuvaukset olivat. Avun saajan kokemat muutokset olivat yhteydessä omaisen suhtautumiseen ja omaisen tilanne apua saavan läheisen suhtautumiseen. Lisäksi osa omaisista oli ikääntyneitä puolisoita, joita koskivat samat rajoitukset ja suositukset kuin avun saajiakin. Tällöin myös ne omaiset, joiden piti olla auttavana osapuolena, joutuivat miettimään, mistä he itse saisivat tarvittavaa apua. Päädyimmekin analysoimaan apua tarvitsevien henkilöiden ja omaisten puheet yhdessä.

Seuraavassa analyysin vaiheessa koodasimme kuvaukset sen mukaan, miten haastateltavat kuvasivat omaa suhtautumistaan lähikontaktien välttämiseen ja mahdollisiin muutoksiin avun saamisessa (kuvio 1). Ryhmittelyssä etsimme koodeista samankaltaisia sekä toisistaan eroavia suhtautumistapoja. Nämä ryhmittelyt yhdistimme laajemmiksi kokonaisuuksiksi eli teemoiksi. Braunin ja Clarken (2006) mukaan teema edustaa eräänlaista vastausten toistuvaa kaavaa ja kuvaa puheen samanlaista tarkoitusta. Muodostamamme teemat edustavat erilaisia suhtautumistapoja sen mukaan, miten haastateltavat kuvasivat koronapandemian vaikutuksia saamaansa apuun ja miten he suhtautuivat mahdollisesti kokemiinsa muutoksiin. 


\section{Esimerkkejä rajoitustoimiin ja hoidon muutoksiin suhtautumisen koodauksesta}

"Ei sille voi mitään." "Ei se muuten hullumpaa oo."

"Ihan samal lailla se on menny, päivä kerrallaan." "Samat hoitajat käyvät tuossa. Ei mikkään huoleta."

"...kyllä se on järjestyny. "

" Mulle se ei ole mikään ylipääsemätön juttu."

"Emmä pelkää mitään."

"En mää niistä kauheesti huolestunu ole."

"Meiän arki sujuu kyllä ihan yhtä hyvin kun ennenkin."
Koodausten ryhmittely

\section{Teema}

Ei ole kokenut vaikutusta

hoivaan, sosiaalisiin kontakteihin tai arjen

sujuvuuteen

NEUTRAALI

On kokenut muutoksia, mutta ne eivät haittaa tai paranna arkea

Positiivisen etsiminen

Muutosten taustalla olevien

syiden sanoittaminen

"Pidän hyvänä että niitä rajotetaan näitä vierailukäyntiä sun muita meinaan et se on valvottua se homma."

"Että mä hyväksyn sen nimenomaan koska hän ei varmasti, kovin paljon kestä että jos se iskee."

"Mä elän sen mukaan ku mitä on ohjeistus."

"Kaikessa kamalassakin on aina niitä hyviäkin puolia."

"Se on aika kurjaa kyllä että, ei tavata ketään, ei ketään." "...kun ei pääse mihkään."

"Kyllähän se jollain tavalla on pelottavaakin."

"...tuntuu tietysti ankaralta..."

"Se on yks harmin asia."

"Mä oon vaimon puolesta huolissaan."

"Tuntuu surkeelta..." "Tuntuu että ne kattoo että mitä sää täällä teet."

"Sunhan pitäs olla siellä neljän seinän sisällä."

"...törkeetä..."

"Se on aika kova juttu ja aikalailla tappavaa sekin jo niin sanotusti vanhuksille."
Sosiaalisten kontaktien vähenemisestä aiheutuva haitta ja huoli

HUOLI

Erimielisyys viranomaisten ja sote-ammattilaisten toiminnan ja päätösten kanssa
Joustaminen tilanteen

mukaan

Kuvio 1. Analyysin eteneminen. Esimerkkejä rajoitustoimiin ja hoidon muutoksiin subtautumisen pubeesta (koodaus), josta on muodostettu kolme teemaa. 


\section{Tulokset}

Haastateltavista seitsemän (kolme kotihoidon ja neljä asumispalveluyksikön asiakasta) ei ollut kokenut mitään muutoksia ja kahdeksan (kolme kotihoidon ja viisi asumispalveluyksikön asiakasta) kertoi muutoksista avun saamisessa (taulukko 1). Yhden asumispalvelussa asuvan henkilön kohdalla jäi epäselväksi, tapahtuiko avun saamisessa muutoksia. Haastateltavien suhtautumista mahdollisiin avun saamisen muutoksiin ja lähikontaktien välttämiseen kuvaavat muodostamamme teemat neutraali, sopeutuminen ja buoli. Sama henkilö saattoi tuottaa useampaa teemaa kuvaavaa puhetta riippuen siitä, puhuttiinko rajoitustoimista yleensä, seurauksista itselle, sosiaalisten kontaktien välttämisestä vai virallisten avuntarjoajien toimista.

Taulukko 1. Haastateltavien kuvaus, koodinimet (nimet muutettu) ja tieto siitä, onko kokenut hoivassa muutoksia.

\begin{tabular}{|l|l|l|}
\hline $\begin{array}{l}\text { Haastatteluihin osallistuvat } \\
\text { henkilöt }\end{array}$ & Normaalioloissa auttavat henkilöt/tahot & $\begin{array}{l}\text { Muutoksia hoidossa/ } \\
\text { hoivassa/avussa }\end{array}$ \\
\hline Apua tarvitseva henkilö (Maire) & Kotihoito, ruokapalvelu, omainen & Ei muutoksia \\
\hline $\begin{array}{l}\text { Apua tarvitseva henkilö (Niilo) } \\
\text { Omainen, lapsi (Sanna) }\end{array}$ & Kotihoito, omaiset & Muutoksia \\
\hline $\begin{array}{l}\text { Apua tarvitseva henkilö (Oskari) } \\
\text { Omainen, lapsi (Mikko) }\end{array}$ & Kotihoito, siivouspalvelu, omaiset & Ei muutoksia \\
\hline Apua tarvitseva henkilö (Pirjo) & Kotihoito, omaiset & Muutoksia \\
\hline Apua tarvitseva henkilö (Akseli) & Kotihoito, siivouspalvelu, omaiset & Muutoksia \\
\hline Apua tarvitseva henkilö (Heikki) & Kotihoito, omaiset & Ei muutoksia \\
\hline Apua tarvitseva henkilö (Eeva) & Asumispalveluyksikön hoitajat & Ei muutoksia \\
\hline Omainen, puoliso (Pertti) & Asumispalveluyksikön hoitajat, omaiset & Muutoksia \\
\hline Omainen, puoliso (Antti) & Asumispalveluyksikön hoitajat, omaiset & Muutoksia \\
\hline Omainen, sukulainen (liris) & Asumispalveluyksikön hoitajat, omaiset & Ei muutoksia \\
\hline Apua tarvitseva henkilö (Raija) & Asumispalveluyksikön hoitajat & Muutoksia \\
\hline Apua tarvitseva henkilö (Maija) & Asumispalveluyksikön hoitajat, omaiset & Ei muutoksia \\
\hline Omainen, lapsi (Jenni) & $\begin{array}{l}\text { Asumispalveluyksikön hoitajat, omainen, } \\
\text { vapaaehtoistyöntekijä }\end{array}$ & Muutoksia \\
\hline Omainen, lapsi (Liisa) & Asumispalveluyksikön hoitajat, omainen & Muutoksia \\
\hline Omainen, sisarus (Jaakko) & Asumispalveluyksikön hoitajat, omainen & Ei tietoa \\
\hline Omainen, lapsi (Petri) & Asumispalveluyksikön hoitajat, omaiset & Ei muutoksia \\
\hline
\end{tabular}

\section{Neutraali}

Neutraalia puhetta tuottaneet vastaajat kertoivat kokeneensa muutoksia avun saamisessa vähän tai ei lainkaan. Heidän kuvailunsa eivät juurikaan sisältäneet myönteisiä tai kielteisiä ilmaisuja. Seuraavat haastateltavat kuvaavat sekä omaisen avun että hoitohenkilöstön toiminnan jatkuvan poikkeustilanteesta huolimatta samanlaisena kuin ennen koronapandemiaa. ( $\mathrm{H}=$ haastattelija, $\mathrm{A}=$ apua tarvitseva henkilö, $\mathrm{O}=$ omainen.)
H: Onks tää vaikuttanu miten arjen sujuvuuteen sitte tää korona? Kauppareissuibin tai apteekissa käymisiin tai...

A: Mulle tulee, apteekki tulee rullassa. Ne tulee, noi hoitajat tuo ne aina. Viime vuoden tapaturman jälkeen ni, sen jälkeen mul on tullu apteekki tavarat. Ennen sitä mä hoidin itte. H: Tuleeks hoitohenkilöstö kuitenkin ihan normaalisti käymään?

A: Joo, ne tulee ihan, joka päivä. Mutta kun mä en tartte muuta kun sen, mitä apua mitä tos on, silmätipat ja kaikkee muuta ja, puke- 
misessa vähän auttaa ja mitä kaikkee muuta. (Oskari)

\section{H: Käykö samat hoitajat kuitenkin edelleen?}

A: Samat hoitajat käyvät tuossa.

H: Ja tosiaan sen saman määrän neljä kertaa päivässä?

A: Näin on. (Heikki)

Koska koronatilanteen tuomat rajoitukset eivät juurikaan tuoneet muutoksia neutraalisti suhtautuvien omaan arkeen, ei heillä ollut merkittävää tarvetta reagoida uuteen tilanteeseen elämässään. Seuraavassa katkelmassa asumispalveluyksikössä asuva haastateltava kertoo eläneensä jo pitkään itsekseen, eikä koronatilanne ole vaikuttanut tähän. Aiemmin haastattelussa hän kertoo, että hänellä ei ole ennen pandemiaa ollut aktiivisia sosiaalisia verkostoja, joista joutuisi nyt olemaan erossa. Koronapandemia ja lähikontaktien välttäminen eivät muuta tätä tilannetta.

A: Mä oon semmonen erakkoluonne, että mä oon ollu, 30 vuotta asunu yksin, eikä siinä oo ollu mitään ongelmaa, niin tää on niin kuin jatkumoo siihen.

H: Iban totta. No koetko että siellä on boidoissa tullu jotain muutoksia tämän tilanteen takia? Onko hoitajia vähemmän tai eikö saa apua jos tarvii?

A: Ei, kyllä täällä hoitajia on ollu ihan että boitajistakaan ei oo kukaan sairastunu, onneks. (Eeva)

Mikäli avun saamisessa tapahtui muutoksia, se ei aina tarkoittanut tilanteen heikentymistä. Seuraava haastateltava kertoi omaisten vierailukiellon myötä hoitohenkilökunnan määrän kasvaneen. Haastateltava mainitsee fysioterapeutin, joka on käynyt hänen kanssaan ulkona. Hän toteaa, että omaiset eivät saa lainkaan vierailla asumispalvelussa ja että virus voi uhata koko maailmaa. Hän ei kuitenkaan kuvaa sitä itselleen ongelmaksi. Hän ei myöskään ole omalla kohdallaan koronavirustartunnasta huolissaan, koska mainitsee olevansa jo niin vanha, että koronatartunnalla ei ole enää merkitystä.

A: Täällä ei käy ketään eikä täältä läbde ketään mibinkään.

H: Miltäs se tuntuu sit että omaiset ei saa käydä?

A: No ei se nyt niin kaubeeta oo. Ei niitä muutenkaan niin paljon oo näbny. Että nyt kun on pubelin ja semmoset. [...]

H: Joo. Mutta sanoit että hoitajia tuntuu olevan nyt enemmän?

A: Joo. Semmosia jotka on muissa hoivalaitoksissa, niin tässä just kävi läbti pois kun pubelimes. Hän on tuolta terveyskeskuksen, fysioterapeutti, että hän vei mua ulos.

H: No buolettaako tulevaisuus ton koronan takia?

A: Tietenkin jos kun on sukulaisia ja läheisiä ibmisiä ja koko maailmaban tässä on uhattuna. Mä oon niin vanha että ei sillä väliä enää oo jos tulis. [...] Mä oon iban tyytyväinen olooni täällä ja oon kiitollinen siitä että saan olla. (Raija)

Kotona asuvien, kotihoitoa saavien haastateltavien oli myös mahdollista jatkaa elämää kuten aiemmin. Seuraavan haastateltavan poika oli tehnyt isommat ostokset isälleen jo ennen pandemiaa, ja he jatkoivat samalla tavalla. Haastateltava kertoo itsekin käyvänsä kaupassa tarpeen tullen. Hän ei koe tilanteen huolettavan häntä eikä koe tekevänsä mitään riskialtista käymällä itse kaupassa.

A: Teen viikottain tilauksen jonka poika boitaa. Jos jotain alkaa kesken viikkoo buomaamaan että, jotain tekis mieli taikka joku alkaa loppuun ni, mä oon itte ajellu ja hakenu. (Akseli)

\section{Sopeutuminen}

Sopeutumisen teema sisältää puhetapoja,joissa pyrittiin näkemään ja kuvaamaan rajoitukset 
hyödyllisen tarkoituksen ja tavoitteen näkökulmasta tai kehittämään uudenlaisia ratkaisukeinoja ottaen huomioon karanteenin kaltaiset olosuhteet ja avun saamisen muutokset. Vaikka muutokset aiheuttivatkin jonkinasteista haittaa, moni haastateltavista totesi, että kyseinen muutos oli kuitenkin välttämätön, jotta saavutetaan tilapäistä haittaa suurempi hyöty eli ihmisten suojeleminen koronavirukselta. Seuraavassa katkelmassa haastateltava omainen kertoo, että tukipalveluja on lopetettu lähikontaktien välttämiseksi. Hän kuitenkin kokee sen olevan oikein, koska hänen mielestään näin on tehty hänen läheisensä hyväksi ja suojelemiseksi. Läheisen turvallisuus on hänelle tärkeintä.

O: Ei kyl mä ymmärrän sen et se on tän omaisen parhaaksi, ni emmä koe sitä mitenkään, emmä halua sitä riskeerata missään nimessä omaista siinä. (Pertti)

Haastateltavat pyrkivät itse etsimään tilanteesta myönteisiä puolia. Seuraava haastateltava osallistui haastatteluun asumispalvelussa asuvan puolisonsa omaisena, mutta hän oli samalla itsekin riippuvainen lastensa avusta. Pandemian ja rajoitusten aikana hän on edelleen luottanut lasten apuun ruokaostosten tekemisessä ja siivoamisessa, vaikka tilanne on vaatinut hieman kekseliäisyyttä, jotta vältytään ylimääräisiltä kontakteilta. Rajoitteiden tuomista muutoksista puhuttaessa haastateltava kuvaa erilaisia asioita, joita voi tehdä, eikä hän koe tilanteessa ongelmia.

A: No ei se minulle ongelmia tuota millään tavalla. Mulla on tää huoltokomppania tässä ympärillä. Minä tarviin ruokaa, ne tuo muovikassin tuohon rappusille ja, aamulla minä pääsen kävelemään, tuonne raitille raittiiseen ilmaan. Ei täs, minulla ei oo mitään ongelmia. Internet on auki. Sillä pääsee vaikka New Yorkin kirjastoon, tai minne tahansa. Televisio on auki ja radiot on auki. Ei mitään ongelmia. [...] Hetkinen, viime lauantaina, niin lauantaina yks tytär tuli tänne hanskat kourassa ja, suusuojuksin varustettuna ja me yhdessä siivottiin, suursiivottiin tämä huusholli ja niin poispäin. Että ei tässä mitään ongelmia oo. (Antti)

Omaisten vierailukielto esti lähikontakteja, mutta tätä kompensoitiin vaihtoehtoisilla kommunikaatiokeinoilla. Moni oli ottanut enenevässä määrin käyttöön tavalliset puhelut ja videopuhelut kuulumisten kysymiseen ja mahdollisimman normaalin kommunikaation ylläpitämiseksi. Seuraavassa haastattelukatkelmassa omainen kuvaa, miten yhteyttä vaimoon ja hoitajiin on pidetty niin puhelinkeskusteluin kuin valokuvin.

O: Hän on edelleen, toki mä en oo päässy siellä 13. päivä alkaen, viime kuuta niin se, ovet säppiin et sinne ei oo sen jälkeen päässy mutta, ollaan pubelimella ja välillä lähettelee valokuvia niin ku tänäänkin tuli valokuvia et ne pyrkii ottaa valokuvia ja sillä tavalla, keskustelee. Mä soittelen sinne sitte suurin piirtein, joka päivä tai joka toinen päivä. Mä koitan varoa vaan, noin normaalisti. (Pertti)

Osa haastateltavista kuvasi muutoksia ja niistä mahdollisesti aiheutunutta haittaa. He eivät suoranaisesti etsineet asiasta positiivista näkökulmaa mutta ilmaisivat ymmärtävänsä tilanteen tuomat haasteet. Seuraavassa esimerkissä kotihoidon asiakas kuvaa tarvitsevansa apua tiettyihin aamutoimiinsa. Koronatilanteen vuoksi hoitajat tulevat myöhemmin, mikä viivästyttää häntä aloittamasta muita päivän toimia. Hän ei kuitenkaan moiti hoitajia tai tilannetta, vaan kerrottuaan aikataulun tuomista haitoista lisää lopuksi, että ei asiassa ole sen kummempaa ja että hoitajat tekevät kuitenkin kaiken tarvittavan.

A: Ne on, tuntuu olevan nämä, kotipalvelun ibmiset entistä tiukemmalla että, kun ne on aamulla tullu yleensä tossa kabdeksan maissa niin nyt se on, menny tonne puoli kymme- 
neen suurin piirtein. Ja se on siitä ollu vähän, ongelmallinen että kun mulle on noi, tukisukkahommat niin mä on paljain jaloin niin kauan kun ne tulee. Että mibinkään lähteminen ei ole, ajateltavissa ennen kun se käy että se, aamuhomma venyy sillä lailla pitemmälle. Ja siinä selitetään että siellä on entistä enemmän, tulee tehtäviä niillä, jotka tätä päiväboitoo käyvät hoitamassa asunnoilla. [...] Ei siinä muuta sen kummempaa ole kun että, ne ajat on vähän epävarmempia, ja myöhäsemmässä melkein kaikki. Että kyl ne auliisti tekee kaikki. (Akseli)

Moni asumispalveluyksikössä asuvista tutkimukseen osallistuneista henkilöistä sairasti muistisairautta. Asukas, jolla oli pitkälle edennyt muistisairaus, ei itse enää kyennyt kertomaan omaiselle tilanteestaan ja mahdollisista muutoksista avun saamisessa. Omainen kertoo seuraavassa katkelmassa, että hän ei oikeastaan tiedä, onko asumispalveluyksikön arjessa tapahtunut muutoksia, mutta pitää lähikontaktien välttämistä hyvänä asiana ihmisten suojelemiseksi tartunnalta.

O: Kyllä se kaiken kaikkiaan ihan hyvält kuulostaa verraten tää tilanteen mikä on ja mikä täs on [eristys]. [...] Ainaki näitten asukkaiden subteen ketä siel on potilaana ni niitten subteen tää on iso riski kerta kaikkiaan. Jos siellä ne on heikkokuntosia tai muuta ni sielt tulee äkkiä jos siellä yks tämmönen menee millä on, sit sanotaan on tämmöstä virushommaa ni totta kai se, se on niin pienestä kii sit se homma. Nii että pidän byvänä että niitä rajotetaan näitä vierailukäyntiä sun muita meinaan et se on valvottua se homma. [...] En mä siinä oikeestaan tiedä et onks se vaikuttanu heidän arkeensa. [...] Olen mä hänelle pubunu, ku mä oon pubelimessa hänen kanssaan pyrkiny pubumaan välillä. Ehkä hän vaistoaa et jotain on olemassa tämmöstä ja muuta mutta ei hän siihen osaa kantaa ottaa. (Jaakko)

\section{Huoli}

Osa vastaajista ilmaisi kokevansa harmia tai huolta koronapandemian itselle tai muille tuomista rajoitteista. Huolta tai harmia aiheuttivat myös avun saamisessa tapahtuneet muutokset. Seuraavassa ensimmäisessä katkelmassa kotihoidon asiakas kuvaa, että on harmillista, kun ei pääse mihinkään kodin ulkopuolelle. Toisaalta kotihoidon käynnit toimivat kuten aina, ja ne ovat karanteenin kaltaisessa olosuhteessa elettäessä ainoa sosiaalinen kontakti, joka ilahduttaa päivän aikana. Jälkimmäisessä katkelmassa asumispalvelun asukas kertoo, että hänen saamaansa apuun ei ole tullut muutoksia, joten hän ei ole kokenut haittaa tai huolta siltä osin, mutta lähikontaktien välttäminen on saanut koronatilanteen tuntumaan ahdistavalta.

A: Kun pääse mibkään niin, ei voi mennä ulos, ei mibinkään. Että se on aika kurjaa kyllä että, ei tavata ketään, ei ketään. Kotihoito käy ilabduttaa siinä mieles, kaks kertaa päivässä käy kotihoito. (Maire)

\section{H: Et kaikki tavallaan hoitopalvelut ja muut} sujuu ihan entiseen tapaan vai näkyyks se siinä sitte mitenkään?

A: Ei näy.

H: Entäs hoitohenkilöstön osalta et onks ollu poissaoloa tai, jotakin sellasta?

A: Ihan se on menny jouhevasti että, emmä ainakaan oo kärsiny. [...]

H: Miltä tää koko tilanne on sinusta tuntunu?

A: No aika abdistavalta kun ei ketään saa käydä. Eikä ittekään saa mennä minkään. (Maija)

Jos ikääntynyt apua tarvitseva henkilö on tottunut saamaan apua läheisiltään, ei tähän välttämättä löydy nopeasti vaihtoehtoisia ratkaisuja, kun vahva suositus lähikontaktien välttämisestä on voimassa. Tällöin eräs tapa suhtautua muutoksiin oli päätyä noudattamaan itselle sopivaksi koettua toimintatapaa, vaikka se olikin vastoin yleisiä suosituksia ja saattoi aiheut- 
taa huolta tai stressiä. Seuraavassa katkelmassa haastateltavan omainen kertoo, että heillä ei ollut muuta keinoa kuin jatkaa vierailuja isänsä luona, koska isä ei olisi selvinnyt ilman apua. Jo ennen koronapandemiaa omaiset olivat auttaneet paljon ja hoito oli perustunut omaisen vahvaan rooliin avuntarjoajana. Omainen $\mathrm{ku}-$ vaa läheisten vierailukiellon tuntuvan "julmalta”. Lisäksi hän pohtii omaisten vierailujen ja suositusten noudattamatta jättämisen riskejä.

A: Ei tää, on vaan yks. Kun ei mibinkään mennä. Ei se muuten hullumpaa oo. Ihan samanlaista kun ennenkin.

O: Niin, kun me ei olla sua eristetty. Me roikutaan tässä kuitenkin kaiken uballakin. [...]

Toi tuntuu tietysti ankaralta se että ne eristetään noi vanhat ibmiset iban kokonaan. Ja kun se porukka on, iäkkäämmät ja täällä maalla varsinkin, ja täällä nää nettiybteydetkin on heikommat, niin ei isällä oo mitään välineitä ja konsteja pitää ybteyttä, jos ei me tässä notkuttaisi. Niin se tuntuu aika julmalta toisaalta, että vähän tuntuu toisaalta siltä että tässä joutuu monet ihmiset vähän niin kuin heitteille. [...]

Jollei sitten omaiset tosiaan kaikesta huolimatta niin pidä huolta, vaikka ois kuinka eristyksissä. Mut sitten tarkottaa sitä että omaisten pitäis pysyä aikalailla eristyksissä. Et sehän tässä on että jos käyt töissä ja sulla on nuorisoo ja sillä tavalla tavallaan niitä tartunnan läbteitä on kotona, niin sellasten on aika vaikee sit buolebtia niistä vanhuksista turvallisesti. (Niilo ja Sanna)

Haastateltava kertoo myöhemmin, että he olivat isän terveyden ja turvallisuuden suojelemiseksi lopulta lopettaneet koronatilanteen ajaksi kotihoidon käynnit lääkkeiden tuontia lukuun ottamatta. Seuraavassa katkelmassa sama omainen kertoo, miten hoito oli muuttunut turvattomaksi. Hän on huolissaan tilanteesta, jossa omaisia koski vahva suositus lähikontaktien välttämisestä, mutta kotihoidon hoitajat vierailivat kuitenkin. Turvattomuutta aiheutti hoitajien vaihtuminen: viikon aikana isän luona kävi useita eri hoitajia, joista jokainen oli potentiaalinen koronaviruksen tartuttaja. Myös suojavarusteiden puute tai niitä koskevat epäselvyydet aiheuttivat epäluottamusta. Tällaisessa tilanteessa omaisen rooli avun antajana korostui.

O: Mutta se mua tässä nyt häiritsee, että mul käsittääkseni terveyden-, siis ne kotipalvelu ja vanhustenhoitokuvioissa, niin täbän saakka boitohenkilökunta on kuvitellut suojaavansa itseään vanbuksilta. Ja kun vanbuksia ei kukaan muu lähentele kuin nämä hoitajat, niin hebän on se riski vanhuksille. Eibän ne vanbukset saa sitä tautia muuta kuin hoitohenkilökunnalta. Eli tää on nyt se mikä on ihan älytön asenne ollu mikä tuntu tuollakin kun mä kotipalveluun soitin. [...] Niin se että täällä nyt vähätellään sitä, ettei tarvi suojautua, niin mun mielestäni se on nyt väärin tässä kuviossa vieläkin. [...] Minä kielsin kotipalvelua käymästä, muuta kun tuomassa lääkkeet saa käydä ja ottamassa verikokeet. Ja joka viikko näkee ainakin kun joka kerran tulee eri tyyppi ilman minkäänlaista suojausta, niin ei se tuntunu oikein asialliselta, kun kaubeesti varoitetaan kuinka vanbusten pitää olla eristyksissä, eikä mekään saatais oikeestaan käydä tässä, mutta sitten et sieltä ravaa vielä ibmiset jotka ei ybtään varo. (Sanna)

Moni haastatelluista omaisista osallistui normaalioloissa läheisensä auttamiseen, vaikka tämä asui ympärivuorokautista hoitoa tarjoavassa asumispalveluyksikössä. Omaiset auttoivat esimerkiksi ruokailussa ja ulkoilussa sekä toimittivat läheiselleen erilaisia tarvikkeita. Vierailukiellon takia omaiset eivät päässeet enää tapaamaan läheistään, ja siten tämän avunsaannissa tapahtui muutoksia, joihin haastateltavat eivät voineet itse vaikuttaa. Seuraava haastateltava on huolissaan siitä, että hänen muistisairas läheisensä ei kykene ymmärtämään, miksi hän ei enää käy vierailuilla kuten aiemmin. Omainen kyseenalaistaa sen, miksi hän ei - terveenä - saa tavata läheistään, mut- 
ta eri ihmisten kanssa työskentelevät hoitajat voivat, vaikka he ovat mahdollisia tartuttajia. Jälkimmäisen katkelman omainen kantaa huolta isänsä tilanteesta, kun asumispalveluyksikköön ei päästetä omaisia.

O: Olen ollu neljättä viikkoo jo omaehtosessa erityksessä, eikä vaimoa pääse kattomaan vaikka minä en ymmärrä kyllä, kun ite oon terve ja, hoitajat käy kolmessa vuorossa töissä niin ne vielä suuremmalla syyllä vois tuua sen viruksen sinne kun mitä minä. [...] Niin on tässä, henkilökohtanen hoito, pukeu-, peseytymisessä, ruokailussa. Päivittäin olen hänen kanssaan, siis joka päivä seurustellu kaks tuntia, siihen asti kunnes tuli tämä kielto, että sinne ei saa tulla. [...] Hän ikävöi niin kaubeesti. Hän ei ymmärrä minkä takia minä en käy. Siihen eristykseen asti minä olin joka päivä ollu bänen ka-, seurustellu bänen kanssaan kaks tuntia ja ulkoiluttanu bäntä. [...] Nyt kun mä en voi käydä niin sitä bän vähän ibmettelee eikä ymmärrä. (Antti)

O: Kuitenki mäki isää oon käyny kattomassa. Yhestä kolmeen kertaan viikossa. Nyt sit ku ei pääse ollenkaan ni tuntuu vähän kurjalle. Ollaan otettu kerran WhatsApp-pubelua sinne. Se isälle kai tuntu vähän vieraalta, mä kysyin et otetaanko taas ni sano et ei oteta, balus pubua pubelimessa. Se on tosi kurjaa isän kannalta, varmaan kokee olevansa vankilassa. (Jenni)

Osa haastateltavista ilmaisi uuteen tilanteeseen ja rajoitustoimien tuomiin muutoksiin liittyvää yleistä huolestuneisuutta tai ahdistuneisuutta, jota he eivät voineet kuin sietää. Seuraava haastateltava kertoo, miten viikoittainen tukipalvelu on jäänyt pois, ja hän kokee tilanteen surkeaksi ja rajoittavaksi. Vanhat ihmiset eivät saa mennä mihinkään, ja kotihoito on ainoa, joka käy vierailulla.

H: No mut hei sitte siiben koronaan ni, miltäs tää koko tilanne on tuntunu?
A: Surkeelta. Rajottaa niin paljon ettei pääse, ees ybtään mibkään. Varsinkin tää [tietty viikonpäivä] nyt sitte ja.

$H$ : [kerhon nimi] on jääny.

A: Joo, Enhän mä ulos enää pääse eikä nyt saa mennäkään ulos. Eibän me saada mibinkään mennä. Pysytään huoneessa. Eikä oo kukaan käyny paitsi kotihoitajat saa käydä. Että ei oo siis, ybtään ajatella taas sitä että, sä oot neljän seinän sisällä, eikä oo mitään muuta kun. Mulla telkkari on päällä. Emmää sitä kattele, mää teen kaikkee muuta mutta täytyy olla ääntä kun ei muuten olis ääntä. Objelmatkin on semmosia ja tämmösiä ettei niistä oo, ne on toisintoja jatkuvasti. Ei niist oo mitään iloo. Nekin vaan koittaa halvalla päästä sitte. (Pirjo)

Vaikka puhelut asumispalveluun olivat toki mahdollisia, monella omaisella kommunikaatio sekä hoidettavan läheisen että hoitohenkilökunnan kanssa oli heikentynyt. Seuraavan haastattelukatkelman omainen ei tiennyt, miten asiat sujuvat asumispalveluyksikössä ja saako läheinen riittävästi apua. Haastateltava kertoo vieneensä aiemmin läheiselleen lisäruokaa. Hän oli huolissaan siitä, saako läheinen nyt riittävän monipuolista ravintoa.

O: Ei o kyllä mitään käsityst [siitä miten korona näkyy hoitokodissa]. Mä en tiedä. Ja itse asias sitä mä vähän oon, ois mielenkiintosta kun pääsis siel, no tietysti on aina erilaisia ibmisiä mutta, määki ku kuitenkin vien sinne niitä hedelmiä ja kaikkia aina niin että tuleeko niitä sitten syötyä. Sitä mä oon tässä vähän tässä miettiny. (Liisa)

\section{Pohdinta}

Selvitimme, miten kotihoidon ja asumispalveluyksikön asiakkaiden hoidon, hoivan ja avun saaminen muuttui koronapandemian alkaessa ja rajoitustoimien tullessa voimaan sekä miten asiakkaat ja heidän omaisensa suhtautuivat 
mahdollisiin muutoksiin. Seitsemässä haastattelussa haastateltavat kertoivat, ettei avun saamiseen ollut tullut muutoksia, kahdeksassa kerrottiin muutoksista, ja yhdessä haastattelussa tilanne jäi epäselväksi. Jaoimme lähikontaktien välttämiseen ja hoivan muutoksiin liittyvät kuvaukset kolmeen teemaan: neutraali, sopeutuminen ja huoli. Tulkitsemme huoliteemaan kuuluvien kuvausten sisällöt sellaisiksi, joita tulisi tulevaisuudessa vastaavissa tilanteissa eniten pyrkiä ennakoimaan ja mahdollisuuksien mukaan julkisin toimin ehkäisemään. Kotona asuville, omaisten apua saaville henkilöille ja heidän omaisilleen huolta aiheutti eristyneisyys ja se, että rajoituksia ei ollut aina mahdollista noudattaa. Asumispalveluyksiköissä asuville vierailukielto aiheutti huolta ja ahdistusta yleisemmin kuin pelko tartunnan saamisesta. On kuitenkin merkillepantavaa, että kukaan haastateltavista ei kuvannut avun saamisen tilannettaan erittäin huonoksi, eikä kukaan kertonut, että apua ei olisi lainkaan saatavilla. Asumispalveluissa hoidon järjestelyt saattoivat muuttua, mutta he, jotka pystyivät itse kertomaan tilanteestaan, eivät kuvanneet muutosten vaikuttaneen hoidon sisältöön. Nämä tulokset ovat samansuuntaiset kuin Terveyden ja hyvinvoinnin laitoksen selvityksessä (Kehusmaa ym. 2021), jonka mukaan virallisten palvelujen asiakkaat olivat pääosin tyytyväisiä palveluiden määrän korona-aikana.

Neutraaleja kuvauksia esittäneet eivät joko olleet kohdanneet muutoksia avun saamisessa, rajoitustoimet eivät olleet juuri vaikuttaneet heidän elämäänsä, tai he eivät vain ilmaisseet muutosten vaikuttaneen elämäänsä myönteisesti tai kielteisesti. Kaikkiaan tässä ryhmässä mahdolliset muutokset avun saamisessa koettiin melko pieniksi. Muutoksiin sopeutuminen oli melko yleistä; sopeutumista kuvasi se, että vastaajat kykenivät tavalla tai toisella mukautumaan tapahtuneisiin avun muutoksiin, eivätkä he suhtautuneet muutoksiin tai rajoituksiin kovinkaan kielteisesti tai huolestuneesti. Pikemminkin he pyrkivät ilmaisemaan mahdollista haittaa aiheuttaneiden muutosten li- säksi jotain myönteistä, kuten tyytyväisyyttä rajoituksiin, joita toimeenpantiin viruksen leviämisen ehkäisemiseksi. He olivat myös keksineet erilaisia vaihtoehtoisia tapoja järjestää apua ja olla yhteydessä toisiinsa. Ostoksia esimerkiksi tuotiin portaille tai omaiset tarjosivat kotiapua turvavälein ja maski kasvoilla. Osa kuvasi avun saamisen muutosten ja rajoitustoimien kielteisiä vaikutuksia, mutta he pyrkivät sopeutumaan niihin, eivätkä ilmaisseet pystyvänsä tai edes haluavansa yrittää vaikuttaa näihin muutoksiin. Huolta sisältävät kuvaukset koskivat lähinnä sosiaaliseen eristäytymiseen ja lähikontaktien välttämiseen liittyvää huolta ja ahdistusta sekä sosiaali- ja terveysalan ammattilaisten tai päättäjien koronatoimien tuottamaa haittaa tai huolta. Huolta ja ahdistusta aiheuttivat epäselvyys hoidon järjestämisessä tai järjestämistavoissa sekä se, että omaiset eivät saaneet vierailla läheisensä luona, mutta hoitohenkilökunta - jonka virustilanteesta tai viruksen välttämistoimista omaiset eivät voineet olla varmoja - sai tavata ikääntynyttä läheistä kuten ennenkin.

Omaisten vierailukielto, oli kyseessä sitten kotihoidon tai tehostetun palveluasumisen asiakas, vaikutti ikääntyneiden avun saamiseen erityisesti sellaisissa tilanteissa, joissa apua tarvitseva oli luottanut omaisten päivittäiseen tai lähes päivittäiseen apuun ennen koronapandemian alkamista. Kuten aiemmassakin tutkimuksessa on tullut esiin (Whitehead \& Torossian 2021) sosiaalisten kontaktien välttäminen aiheutti huolta läheisten tilanteesta ja lisäsi yksinäisyyden kokemuksia. Koronaviruksen ja rajoitustoimien tuomiin muutoksiin suhtautumista näytti helpottavan, jos vastaaja kykeni suhteuttamaan muutoksia pandemian tuomiin riskeihin tai muihin elämässä koettuihin haasteisiin. Stressitekijöiden suuruuden lisäksi ikääntyneiden ihmisten erilaiset ominaisuudet ja kyky sietää stressitekijöitä vaihtelevat yksilöllisesti erilaisissa kriisitilanteissa (ks. myös Pearman ym. 2021).

Asumispalveluissa vierailukiellot olivat ehdottomia, eikä niitä voinut pyörtää omalla pää- 
töksellä. Osa haastatelluista koki asumispalveluyksiköiden vierailukiellosta ahdistusta, joka vaikutti olevan suurempaa kuin koronatartunnan pelko. Eduskunnan oikeusasiamies (2020) onkin todennut, että asumispalveluyksiköihin kohdistunut ehdoton vierailukielto on tuskin enää mahdollinen tulevaisuudessa. Jos hoitoa saava henkilö ei pysty itse ilmaisemaan läheiselleen omia kokemuksiaan, hän on poikkeustilanteessa erityisen havoittuvassa asemassa. Kaikkien ympärivuorokautisissa asumispalveluissa asuvien henkilöiden tilanteesta ei saatu tietoa; he eivät itse pystyneet kertomaan tilanteesta esimerkiksi pitkälle edenneen muistisairauden vuoksi, tai he eivät ehkä ymmärtäneet, mistä koronaviruksessa oli kyse. He myös jäivät vaille omaisten tuomaa apua tiukan vierailukiellon vuoksi. Dementiaa sairastavia onkin kuvattu joukoksi, jonka elämää ja hoivaa erilaiset rajoitustoimet koskettivat huomattavasti (Barros ym. 2020).

Yksityisessä kodissa asuvat ihmiset olivat vapaampia päättämään, missä määrin he noudattivat esimerkiksi lähikontaktien välttämistä. He pystyivät edelleen sopimaan omaisten kanssa uudenlaisista toimintatavoista, ja he pystyivät sopeuttamaan omia toimiaan ja käyttämään vapaammin ongelmanratkaisukykyään koronapandemian tuomissa haasteissa. Siten kotona asuvien haastateltavien suurempi päätäntävalta omista asioistaan kuulostaa myönteiseltä. Kääntöpuolena on se, että osa kotona asuvista ei noudattanut annettuja suosituksia, koska niiden noudattaminen olisi jättänyt apua tarvitsevan henkilön vaille riittävää apua. On selvää, että jos rajoitustoimista aiheutuva haitta on niin suuri, että sen koetaan vaarantavan ihmisen hyvinvoinnin suuremmalla todennäköisyydellä kuin pandemia, ihmiset päättävät olla noudattamatta rajoituksia.Tämä saattaa lisätä myös omaisten huolta ja rasitusta, joka Chanin ja kumppaneiden (2020a) mukaan kasvoi pandemian aikana. Jotta rajoittamistoimet olisivat mahdollisimman tehokkaita, onkin erittäin tärkeää, että tulevaisuudessa vastaavissa tilanteissa rajoitukset ja niiden toteut- tamistavat mietitään sellaisiksi, että ihmisten on mahdollista noudattaa niitä.

Suomessa yhteiskunnan ja sosiaali- ja terveydenhuollon varautuminen koronapandemian kaltaiseen tilanteeseen on arvioitu riittämättömäksi, vaikka erilaisia varautumis- ja omavalvontasuunnitelmia yllättävien kriisitilanteiden, myös tarttuvien tautien, varalle on toki olemassa (Ylinen ym. 2021). Varautumissuunnitelmat yllättävien kriisien varalle näyttävät kohdistuvan enemmän virallisiin palveluihin (STM 2008) ja tarttuvan taudin leviämistä estäviin toimiin (STM 2012) kuin esimerkiksi omaisten tarjoamaan ja muuhun epäviralliseen apuun. Omaisten tarjoaman hoivan ja avun osuus ja merkitys on jossain määrin unohdettu, vaikka myös pandemian tuomassa kriisissä omaiset eli epävirallisen avun tarjoajat voisivat olla keskeinen resurssi, joka paikkaa virallisen hoidon tarjontaa ja puutteita (Chan ym. 2020b; Wang ym. 2020). Sosiaali- ja terveysministeriön varautumissuunnitelmassa (2012) mainitaan, että pandemian aikana osalle koteihinsa ilman riittävää apua jääville kotihoidon asiakkaille on järjestettävä tilapäistä joukkomajoitusta, kuten laitostyyppistä hoitoa. Tällainen ei tiettävästi toteutunut. Omaishoidon varalle - myös sellaisen, jossa omaishoitajalla ei ole virallista omaishoidon sopimusta - tarvittaisiin kattavampi varautumissuunnitelma. Kotona asumisen tärkeyttä korostavassa hoivapolitiikassa (STM 2020) ja omaisten apuun nojaavissa käytännöissä tulisi huomioida nykyistä enemmän vaihtoehtoiset toimintatavat äkillisten kriisitilanteiden varalle.

\section{Tutkimuksen vahvuudet ja rajoitteet}

Tutkimusaineistoa kerättäessä alkuperäinen tarkoitus ei ollut kerätä tietoa koronaan liittyvistä tilanteista, vaan koronapandemia alkoi kesken kolmessa osassa toteutetun aineistonkeruun. Tämän voi nähdä sekä vahvuutena että heikkoutena. Vahvuus oli se, että haastattelija tunsi jo entuudestaan haastateltavat ja oli keskustellut heidän kanssaan hoitojärjestelyihin liittyvistä asioista. Tämä edisti hoivassa ja 
avussa tapahtuneiden muutosten selvittämistä nopeasti muuttuvassa tilanteessa. Heikkous on puolestaan se, että alun perin pilottitutkimusta varten koottu haastateltavien joukko oli pieni. On hyvin mahdollista, että hoidon muutoksiin liittyviä kuvauksia olisi enemmän suuressa haastattelujoukossa. Tutkittavat kuuluivat yhden keskisuuren kunnan alueen järjestämien palvelujen piiriin. Siten heidän kokemansa muutokset ovat ainakin jossain määrin kuvauksia juuri kyseisen kunnan palvelujen järjestämistavoissa tapahtuneista muutoksista, eivätkä ne välttämättä vastaa muualla koettuja tilanteita. Toisaalta tämän tutkimuksen tarkoituksena on kuvata ihmisten muutoksiin suhtautumisen tapoja eikä niinkään kartoittaa kaikkia mahdollisia muutoksia tai muutosten laajuutta. Aineisto soveltuu tähän tarkoitukseen pienuudestaan huolimatta. Aineistoon etsittiin apua tarvitsevia henkilöitä, mutta osa heidän sijaisvastaajinaan toimineista omaisista tarvitsi itsekin apua. Siten joidenkin haastateltavien kohdalla raja apua tarvitsevan henkilön ja sijaisvastaajan välillä on häilyvä. Haastattelut ja siten haastateltavien kokemukset sijoittuvat koronapandemian alkuvaiheeseen. On mahdollista, että hoidossa on tapahtunut koronatilanteen pitkittyessä lisää muutoksia, ja siten myös haastateltavien kokemukset ovat saattaneet muuttua ajan kuluessa.

Rajoitteistaan huolimatta tutkimus tuottaa tietoa siitä, mitkä ovat apua tarvitsevien ikääntyneiden hoidon vahvuudet ja heikot kohdat äkillisessä yhteiskunnallisessa kriisitilanteessa. Lisäksi tulokset antavat tietoa siitä, millaisin eri tavoin ikääntyneet ja heidän omaisensa suhtautuvat hoivan ja avun saamisen ja tarjoamisen haasteisiin ja miten heidän tilannettaan voitaisiin helpottaa yhteiskunnallisin toimin. Tämä on tietojemme mukaan ensimmäinen suomalainen tutkimus, jossa keskitytään koronapandemian aiheuttamiin muutoksiin ikääntyneiden avun saamisessa ja siihen, miten ihmiset kuvaavat omaa suhtautumistaan näihin muutoksiin. Ikääntyneet olivat ja ovat tämän ar- tikkelin kirjoittamishetkellä se joukko, jonka elämään ja arkeen koronapandemia vaikuttaa voimakkaasti. Siten heidän kykynsä mukautua tilanteeseen - ja yhteiskunnan sekä sosiaali- ja terveyspalvelujärjestelmän kyky tehdä heidän mukautumisensa mahdolliseksi - on oleellinen osa koko yhteiskunnan kriisistä selviytymisen kykyä.

\section{Johtopäätökset}

Kotona asumista suosivassa hoivapolitiikassa on aukko äkillisiin kriisitilanteisiin varautumisessa. Tämä koskee etenkin niitä kotona asuvia, jotka saavat säännöllisesti omaisten apua. Asumispalveluyksiköissä asuviin verrattuna kotona asuvilla ihmisillä ja heidän omaisillaan oli suuremmat mahdollisuudet päättää, noudattivatko he omaisten vierailukieltoa, ja keksiä korvaavia tapoja arjesta selviytymiseen. Osa ei voinut noudattaa rajoituksia. Rajoitusten ja suositusten noudattaminen olisi jättänyt heidät ilman riittävää tai turvalliseksi koettua apua. Asumispalveluissa hoidon järjestelyt saattoivat muuttua, mutta he, jotka pystyivät itse kertomaan tilanteestaan, eivät kuvanneet muutosten vaikuttaneen hoidon sisältöön. Toisaalta asumispalveluyksiköissä asuvien ihmisten tilanne voi jäädä pimentoon, koska omaiset eivät päässeet heitä tapaamaan, eivätkä he itse välttämättä pystyneet kertomaan mahdollisista haasteista. Myönteistä oli se, että haastateltavat kokivat melko vähän muutoksia virallisessa avussa, eikä kukaan haastateltavista kokenut tilannettaan avun saamisessa erittäin huonoksi. Tulevaisuudessa vastaavissa tilanteissa omaisten avun varassa olevilla henkilöllä tulisi olla mahdollisuus joustavampiin ratkaisuihin kuin koronapandemian aikana on pystytty suosittelemaan. Haasteellisten tilanteiden tuomiin muutoksiin on helpompi mukautua, jos yhteiskunnan suositukset ja toimet tukevat mukautumista toteuttamiskelpoisin tavoin. 
Ikääntyneiden hoidon kustannukset ja raboitus -pilottitutkimuksen on rahoittanut Kunnallisalan kebittämissäätiö.

\section{Yhteydenotto:}

Mari Aaltonen, $\mathrm{Tt} \mathrm{T}$ (gerontologia), dosentti

(yhteiskuntapolitiikka)

Yhteiskuntatieteiden tiedekunta (terveystieteet) ja Gerontologian tutkimuskeskus, Tampereen yliopisto mari.aaltonen@tuni.fi

\section{Kirjallisuus}

Barros D, Borges-Machado F, Ribeiro Ó, Carvalho J. Dementia and COVID-19: the ones not to be forgotten. Am J Alzheimers Dis Other Demen 2020;35.

https://doi.org/10.1177/1533317520947505

Braun V, Clarke, V. Using thematic analysis in psychology. Qual Res Psychol 2006; 3(2):77-101. https://doi.org/10.1191/1478088706qp063oa

Chan EYY, Lo ESK, Huang Z, Kim JH, Hung H, Hung KKC, et al. Characteristics and well-being of urban informal home care providers during COVID-19 pandemic: a population-based study. BMJ Open 2020a;10:e041191. https://doi.org/10.1136/bmjopen-2020-041191

Chan EYY, Gobat N, Kim JH, Newnham EA, Huang $\mathrm{Z}$, Hung $\mathrm{H}$, et al. Informal home care providers: the forgotten health-care workers during the COVID-19 pandemic. Lancet 2020b;27(395):1957-9.

https://doi.org/10.1016/S01406736(20)31254-X

Cohen LW, Zimmerman S, Reed D, Sloane PD, Beeber AS, Washington $\mathrm{T}$, et al. Dementia in relation to family caregiver involvement and burden in long-term care. J Appl Gerontol 2014;33(5):52240. https://doi.org/10.1177/0733464813505701

Comas-Herrera A, Zalakaín J, Lemmon E, Henderson D, Litwin C, Hsu AT, et al. Mortality associated with COVID-19 outbreaks in care homes: early international evidence. 2020 . Internet: https://1tccovid.org/2020/04/12/mortality-associated-with-covid-19-outbreaks-in-care-homes-early-international-evidence/ (viitattu 5.1.2021).

Eduskunnan oikeusasiamies. Hoivakodin menettely vierailuissa ja hoidon sisällössä koronapandemian aikana. 7.10.2020 EOAK/3359/2020 Internet:
Hoivakodin menettely vierailuissa ja hoidon sisällössä koronaepidemian aikana (pdf) (viitattu 18.3.2021).

Finne-Soveri H, Heikkilä R, Mäkelä M, Asikainen J, Vilkko A, Andersson S, ym. Mitä on huomioitava vanhusten laitoshoitoa vähennettäessä. Teoksessa: Noro A, Alastalo H, toim. Vanhuspalvelulain 980/2012 toimeenpanon seuranta: tilanne ennen lain voimaantuloa vuonna 2013. Raportti 13/2014. Helsinki: THL. Internet:

https://www.julkari.fi/handle/10024/116151 (viitattu 7.2.2021).

Forma L, Aaltonen M, Pulkki J. COVID-19 and clients of long-term care in Finland - impact and measures to control the virus. LTC Respones to COVID-9. International Long-term care Policy Network. 2020. Internet: https://ltccovid.org/2020/06/14/new-reportcovid-19-and-clients-of-long-term-care-in-finland-impact-and-measures-to-control-the-virus/ (viitattu 8.11.2020).

Fuller HR, Huseth-Zosel A. Lessons in resilience: initial coping among older adults during the COVID-19 pandemic. Gerontologist 2021;61(1):114-25.

https://doi.org/10.1093/geront/gnaa170

Kehusmaa S, Siltanen S, Leppäaho S. Hyvinvointi korona-aikana: tuloksia vanhuspalvelujen asiakastyytyväisyyskyselystä. Terveyden ja hyvinvoinnin laitos. Tutkimuksesta tiiviisti 10/2021. https://www.julkari.fi/handle/10024/141069

Pearman A, Hughes ML, Smith EL, Neupert SD. Age differences in risk and resilience factors in COVID-19-related stress. J Gerontol B Psychol Sci Soc Sci 2021;76(2):e38-44. https://doi.org/10.1093/geronb/gbaa120

Petzold MB, Bendau A, Plag J, Pyrkosch L, Mascarell Maricic L, Betzler F, et al. Risk, resilience, psychological distress, and anxiety at the beginning of the COVID-19 pandemic in Germany. Brain Behav 2020;10:e01745.

https://doi.org/10.1002/brb3.1745

Pirhonen J, Pietilä I. Patient, resident, or person: recognition and the continuity of self in long-term care for older people. J Aging Stud. 2015;35:95-103. https://doi.org/10.1016/j.jaging.2015.05.004

Pirhonen J, Blomqvist K, Harju M, Laakkonen R, Lemivaara M. Etäläheiset - hoivakotien koronaeristys asukkaiden läheisten kokemana. Gerontologia 2020;34(3):178-92. https://doi.org/10.23989/gerontologia.95669 
Pirhonen J, Seppänen M, Pietilä I, Tuominen K, Jylhä M. Vanhuus ja sosiaalinen kuolema: sosiaalisen kuoleman käsitteistö vanhojen ihmisten haastattelupuheessa. Yhteiskuntapolitiikka 2021;86(1):5-15.

https://www.julkari.fi/handle/10024/140990

Sariola S (2021). Korona koettelee vanhuksia. Lääkärilehti. Ajankohtaista 22.1.2021;76:90- 3. Internet: https://www.laakarilehti.fi/ajassa/ajankohtaista/korona-koettelee-vanhuksia/ (viitattu 10.05.2021).

STM. Sosiaali- ja terveysministeriö. Sosiaalitoimen valmiussuunnitteluopas. Sosiaali- ja terveysministeriön julkaisuja 2008:12.

http://urn.fi/URN:ISBN:978-952-00-2603-5

STM. Sosiaali- ja terveysministeriö. Kansallinen varautumissuunnitelma influenssapandemiaa varten. Sosiaali- ja terveysministeriön julkaisuja 2012:9.

http://urn.fi/URN:ISBN:978-952-00-3347-7

STM. Sosiaali- ja terveysministeriö. Laatusuositus hyvän ikääntymisen turvaamiseksi ja palvelujen parantamiseksi 2020-2023: tavoitteena ikäystävällinen Suomi. Sosiaali- ja terveysministeriön julkaisuja 2020:29. Internet: https://julkaisut.valtioneuvosto.fi/bitstream/handle/10024/162455/ STM_2020_29_J.pdf?sequence=1\&isAllowed=y (viitattu 31.8.2021).

Teräväinen P. Kotona asuvien avun ja palvelujen riittävyys. Pro gradu -tutkielma. Tampereen yliopisto, Yhteiskuntatieteellinen tiedekunta, 2021. http://urn.fi/URN:NBN:fi:tuni-202104263614

THL. Terveyden ja hyvinvoinnin laitos. Tilannekatsaus koronaviruksesta. Päivitetty pe 9.4.2021. Internet: https://thl.fi/fi/web/infektiotaudit-ja-rokotukset/ajankohtaista/ajankohtaista-koronaviruksesta-covid-19/tilannekatsaus-koronaviruksesta (viitattu 9.4.2021).

Tiirinki H, Tynkkynen LK, Sovala M, Atkins S, Koivusalo M, Rautiainen P, Jormanainen V, Keskimäki I. COVID-19 pandemic in Finland - preliminary analysis on health system response and economic consequences. Health Policy Technol 2020;9(4):649-62.

https://doi.org/10.1016/j.hlpt.2020.08.005
Van Aerschot L. Vanhusten hoiva ja eriarvoisuus: sosiaalisen ja taloudellisen taustan yhteys avun saamiseen ja palvelujen käyttöön. Acta Electronica Universitatis Tamperensis 1458. Tampereen yliopisto, 2014. https://urn.fi/URN:ISBN:978-951-44-9568-7

Valtioneuvosto. Mitä yli 70-vuotiaan pitää ottaa huomioon koronavirustilanteessa? Sosiaali- ja terveysministeriön tiedote 19.3.2020a. Internet: https://valtioneuvosto.fi/-/1271139/mita-yli-70-vuotiaan-pitaa-ottaa-huomioon-koronavirustilanteessa- (viitattu 16.2.2021).

Valtioneuvosto. Hallitus on todennut yhteistoiminnassa tasavallan presidentin kanssa Suomen olevan poikkeusoloissa koronavirustilanteen vuoksi. Opetus- ja kulttuuriministeriö, Sosiaali- ja terveysministeriö, Valtioneuvoston viestintäosasto 16.3 .2020 b. Internet: https://valtioneuvosto. fi/-//10616/hallitus-totesi-suomen-olevan-poikkeusoloissa-koronavirustilanteen-vuoksi (viitattu 16.2.2021).

Verity R, Okell LC, Dorigatti I, Winskill P, Whittaker C, Imai N, ym. Estimates of the severity of coronavirus disease 2019: a model-based analysis. Lancet Infect Dis 2020;20(6):669-77. https://doi.org/10.1016/S1473-3099(20)302437.

Wang H, Li T, Barbarino P, Gauthier S, Brodaty $\mathrm{H}$, Molinuevo JL, et al. Dementia care during COVID-19. Lancet 2020;395(10231):1190-1. https://doi.org/10.1016/S0140-6736(20)307558

Whitehead BR, Torossian E. Older adults' experience of the COVID-19 pandemic: a mixed-methods analysis of stresses and joys. Gerontologist 2021;61(1):36-47. https://doi.org/10.1093/ geront/gnaa126

Ylinen T, Ylinen V, Kalliomaa-Puha L, Ylinen S. Governmental response to the COVID-19 pandemic in Long-Term Care residences for older people: preparedness, responses and challenges for the future. MC COVID-19 working paper 04/2021. 